Przegląd Badań Edukacyjnych

ISSN 1895-4308

nr $18(1 / 2014)$, s. 103-114

METAANALIZY

BADAŃ

EDUKACYJNYCH

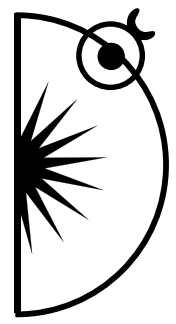

Zenon Gajdzica

\title{
0 pozycji badacza w poznawaniu świata osób niepełnosprawnych
}

DOI: http://dx.doi.org/10.12775/PBE.2014.008

\section{Wprowadzenie}

Kwestia pozycji badacza i jego relacji z obiektem badań nie należy do zagadnień pomijanych na gruncie nauk społecznych i humanistycznych. Przeciwnie, jest stosunkowo często podejmowana, zwłaszcza w obszarze antropologii kulturowej / społecznej i socjologii (np. Konecki 2000; Dehnel 2005; K. Kość-Ryżko 2013; H. Schuman 2013). Podjęcie tego tematu usprawiedliwia - jak sądzę - jego absencja na gruncie pedagogiki specjalnej. Tymczasem zagadnienie to wydaje się istotne nie tylko ze względu na możliwe relacje badacza z obiektem badań (te, pomijając swoisty kontekst, pozostają typowe dla badań w obszarze nauk społecznych i humanistycznych), ale także z uwagi na fakt, że najczęściej badania nad światem osób niepełnosprawnych prowadzą badacze zwykle nieobarczeni niepełnosprawnością.

Pojęcie świata osób niepełnosprawnych utożsamiam nie tyle z fizycznie wyznaczonym środowiskiem zarezerwowanym dla tej grupy (np. instytucji opieki całodobowej, czy szkoły specjalnej), ale przede wszystkim z przestrzenią zredukowanych możliwości realizowania zadań życiowych, przyjmując, że redukcja ta stanowi przede wszystkim konsekwencję postaw społecznych, ale także ograniczonych możliwości samej osoby niepełnosprawnej. To zaś w nawiązaniu do uwagi poczynionej wyżej prowadzi do sytuacji, w których sam 
badacz na ogół nie doświadcza barier fizycznych, ani ograniczeń sprokurowanych społecznie w wyniku niesymetrycznych relacji, nadmiernego dystansu, czy stereotypów.

Celem opracowania jest zaprezentowanie autorskiej propozycji typów badaczy nawiązujących do ich pozycji w relacji do badanego świata osób niepełnosprawnych oraz przyjmowanej roli w procesie badania. Stanowi ona punkt wyjścia analizy wybranych koncepcji badań prowadzonych na gruncie pedagogiki specjalnej w ostatnich latach. Zdaję sobie sprawę, że ramy opracowania nie pozwolą na dogłębną i wielowątkową analizę podjętego tematu, co naraża na zarzut powierzchowności. W związku z tym już na wstępie zastrzegam, że opracowanie stanowi jedynie zasygnalizowanie problematyki pozycji i roli badacza oraz niektórych konsekwencji tego ulokowania w zakresie gromadzenia $\mathrm{i}$ analizowania danych.

\section{Typy badaczy w poznaniu świata osób niepełnosprawnych}

1. Typ poznania. Pozycja badacza w relacji do badanego obiektu warunkuje typ poznawania (stosunku poznawczego między podmiotem a przedmiotem poznawanym). Jedna z najprostszych, a zarazem bardziej przydatnych do dalszych rozważań, typologii poznawania opiera się na kryterium bezpośredniości i prowadzi do rozróżnienia poznania (poznawania) bezpośredniego i pośredniego. W pierwszym przypadku obiekt poznania zostaje naocznie (przez zmysły) poznany $\mathrm{w}$ oryginale, $\mathrm{w}$ drugim zaś proces ten odbywa się za pośrednictwem określonego reprezentanta i nie występuje w charakterze samoobecności (Ingarden 1995, s. 22-23).

2. Badanie faktów i sądów o faktach. Zbliżona (choć nie identyczna) linia podziału dotyczy badania faktów lub sądów o faktach (Pilch, Bauman 1998, s. 21). Naturalnie te pierwsze można badać (używając określenia Romana Ingardena) naocznie w oryginale, drugie - za pośrednictwem, opierając się na relacjach innych osób lub na wytworach opisujących badany obiekt. Naturalnie można także przyjać, że istnieją wytwory (relacje, dokumenty, wyniki innych badań), które obiektywnie opisują badany wycinek rzeczywistości, dostarczając jednocześnie pośrednich danych o faktach. To jednak pozostaje w związku z przyjętą strategią badań i umieszczeniem jej w określonej teorii postrzegania i rozumienia świata.

3. Ulokowanie wewnątrz lub $z$ zewnątrz badanego świata. $W$ trakcie gromadzenia danych badacz może znajdować się wewnątrz badanego świata. W praktyce oznacza to zwykle uczestniczenie, bezpośrednie relacje i oddziały- 
wanie na obiekt badań. Bywa, że łączy się z obecnością stosunkowo bierną, bez bezpośrednich relacji i wpływu na zmianę badanego wycinka rzeczywistości. Z kolei impostacja na zewnątrz to postrzeganie pośrednie, gromadzenie i analizowanie danych zastanych, czasem sprokurowanych, ale z pewnego dystansu.

Połączenie wskazanych trzech zmiennych we wzajemnych relacjach zostało w nieco uproszczony sposób zobrazowane graficznie na schemacie $\mathrm{nr} 1$. Perspektywa wewnętrzna i zewnętrzna zostały doprecyzowane typami badaczy, nazwanymi (metaforycznie) ze względu na stosowane przez nich strategie zbierania danych. Oczywiście jest to podział umowny i jak w przypadku większości prób odtworzenia rzeczywistości w schemacie nieco uproszczony i nie w pełni konsekwentny. Niemniej jednak, jak sądzę, przydatny w dalszej analizie pozycji badacza w poznaniu sytuacji społecznej osób niepełnosprawnych.

Schemat nr 1. Perspektywy poznawania świata osób niepełnosprawnych

\section{Perspektywa zewnętrzna}

Wprawdzie brakuje na gruncie pedagogiki specjalnej szerszych analiz statystycznych stosowanych strategii badawczych i badań nad najczęściej użytkowanymi metodami i technikami badawczymi, ale już pobieżna analiza prac empirycznych (Gajdzica 2009, s. 62-65) pokazuje, że to popularna perspektywa badań, zwykle osadzona w pozytywistycznym paradygmacie postrzegania świata. Przesłanką zachęcającą do przyjęcia tej perspektywy jest założenie, że „aby zrozumieć, jest niesłychanie ważne, aby osoba, która stara się zrozumieć, była umiejscowiona na zewnatrz przedmiotu jej twórczego zrozumienia - w innym czasie, przestrzeni, kulturze. Człowiek nie może zobaczyć samego siebie z zewnątrz, przynajmniej nie w całości - nie pomogą tu ani lustra, ani fotografie. Tylko inni ludzie mogą przeżyć w pełni wartość mojego ciała zewnętrznego, dlatego że są umiejscowieni na zewnątrz mnie i dlatego że są inni" (za: Czarniawska 2012, s. 73). Perspektywa zewnętrzna pozwala na szeroki, perspektywiczny ogląd, często związany ze zbieraniem danych w wielu miejscach, nie musi łączyć się z koniecznością obecności badacza w trakcie zbierania danych (np. kwestionariusz ankiety). Poznanie (gromadzenie danych i ich wyjaśnianie) wymaga dystansu emocjonalnego do obiektu badań. W tej perspektywie częściej stosuje się wystandaryzowane narzędzia oraz sprecyzowane kryteria doboru grupy.

Badacza określonego mianem zbieracza powinna charakteryzować teoretyczna założeniowość, która wymaga dobrej orientacji w przedmiocie badań. Może ona wynikać z analizy teoretycznych podstaw problemu badawczego, 
znajomości wyników zbliżonych badań, przeprowadzenia badań pilotażowych, rzadziej własnego doświadczenia. $\mathrm{W}$ omawianym przypadku poznawania świata osób niepełnosprawnych badacz nie jest zatem zwykle osobiście dotknięty niepełnosprawnością (jeżeli jest, to niekoniecznie wykorzystuje te doświadczenia), nie musi posiadać praktyki relacji z osobami niepełnosprawnymi.

Zbiera dane za pomocą autorskich lub zapożyczonych narzędzi. Sztandarowym przykładem jest kwestionariusz ankiety, przy użyciu, którego zbieracz zwykle gromadzi opinie o przedmiocie badań lub spostrzeżenia osób badanych na jego temat. To oczywiście niesie ze sobą konkretne następstwa w postaci wyjaśniania danych. Przede wszystkim powinien on przyjąć, że poznaje pośrednio wycinek rzeczywistości i zakładać, że są to spostrzeżenia konkretnych osób obarczone ich doświadczeniem i nastawieniem do opisywanego obiektu. Jeżeli zbieracz lokuje badania np. w konstruktywistycznym sposobie rozumienia świata, może uznać, że badany świat jest taki, jakim widzą go badani. W przypadku osadzenia swoich analiz, np. w teoriach funkcjonalno-strukturalnych konieczny jest dystans do obiektywności danych. Zbieracz może wykorzystywać także narzędzia wystandaryzowane, np. testy. Wówczas może traktować je jako obiektywne informacje np. co do poziomu wiedzy na określony temat.

Zbieracz jest zatem ulokowany poza światem badanym, a to pozwala mu na uzyskanie dystansu do tego świata, charakteryzuje go założeniowość teoretyczna i wiedza globalna, zebrane informacje traktuje jako zbiór danych wypełniających określone pole badawcze. Nie łączy poznania z działaniem, ale w toku zbierania danych może gościć w badanym świecie. W toku analizy nie interpretuje, a raczej wyjaśnia dane, odwołując się do szerszego kontekstu teoretycznego, tworząc określony porządek.

W przyjętej typologiijeszcze większy dystans wobec badanego świata cechuje myśliwego. Korzysta on z danych zastanych, zebranych przez różnego rodzaju agendy, instytucje - niekoniecznie w celach badawczych. Może też wykorzystywać dane zebrane przez innych badaczy, dokonywać ich uogólnienia, oglądu z innej perspektywy, czasem przyjmując postawę pasożytniczą. Myśliwy analogicznie jak zbieracz także ulokowany jest poza światem badanym. Konstruowany przez niego proces badawczy nie wymaga kontaktu z nim, nie musi go cechować jakiekolwiek doświadczenie własnej niepełnosprawności. Posiada jednak wiedzę teoretyczną na temat badanego wycinka rzeczywistości. Myśliwy w przeciwstawieniu do zbieracza posiłkuje się przede wszystkim metodą analizy treści (np. danych zawartych w raportach okręgowych komisji egzaminacyjnych, danych statystycznych GUS, czy zbiorach artykułów prasowych itp.). Między nim a badanym światem zatem zawsze pojawia się jeszcze jeden pośrednik - 
zbieracz. Dlatego też pracuje on na materiale większej abstrakcji, dokonując kolejnej analizy.

\section{Perspektywa wewnętrzna}

Przesłanką do wykorzystywania tej perspektywy jest założenie, że obserwator „nigdy nie będzie miał lepszej wiedzy niż aktorzy, cudzoziemiec nigdy nie pojmie lepiej tubylczej kultury niż tubylcy, ale obserwator i cudzoziemiec mogą mieć inny obraz działania czy kultury niż aktorzy i tubylcy" (Czarniawska 2012, s. 73).

Przyjęcie wewnętrznej perspektywy poznania świata osób niepełnosprawnych łączy się z założeniem, że opisanie, zrozumienie i wyjaśnienie badanego wycinka rzeczywistości wymaga bycia w badanym świecie. To zaś może, ale nie musi, wiązać się z jego zmienianiem. Pozycja ta zwykle wkomponowuje zaangażowanie emocjonalne badacza w postrzeganie badanej rzeczywistości. Naturalnie jego emocje tworzą swego rodzaju kontekst obserwowanych zjawisk, nie należy ich traktować jako danych empirycznych, moga jednak być użytecznym narzędziem analitycznym (Konecki 2000, s. 155). W tym układzie badacz narażony jest na dylematy etyczne, związane z pytaniami o granice wglądu w życie badanych, odkrywanie pokładów intymnych, czasem także wstydliwych i bolących. Oczywista jest troska o dobrostan emocjonalny informatorów, która powinna być swoistym barometrem $\mathrm{w}$ interakcjach badacza $\mathrm{z}$ badanym (Kość-Ryżko 2013, s. 19), ale często rywalizuje ona z naukową wartością pozyskanego zbioru informacji, co nie ułatwia wyborów w zakresie formułowania problematyki badań i zachęca do unikania tematów trudnych. Bliskim problemem jest kwestia kalania swojego gniazda. Pojawia się on w przypadku badań nad swoim środowiskiem zawodowym lub lokalnym. Ujawnianie niektórych informacji lub ich krytyczna interpretacja może prowadzić do konfliktów personalnych badacza. Jeszcze inny problem dotyczy odsłaniania wypartych przez badanego problemów i uświadamiania mu ich faktycznego istnienia (por. Orzechowska, Talarowska, Zboralski, 2013).

Odnosząc perspektywę wewnętrzną do badań nad światem osób niepełnosprawnych, nie sposób pominąć kwestii doświadczenia niepełnosprawności przez badacza. Jest ona, jeżeli nie konstytutywnym to przynamniej ważnym, warunkiem interpretacji danych, który de facto zostaje spełniony w związku $\mathrm{z}$ obecnością badacza w tym świecie. Doświadczenie własne niepełnosprawności może wynikać $\mathrm{z}$ bycia osobą obarczoną niepełnosprawnością, trwałego (lub przynajmniej okazjonalnego, ale systematycznego) kontaktu z ludźmi niepełno- 
sprawnymi w środowisku rodzinnym, lokalnym, zawodowym. Uczestniczenie w tym świecie i związane z nim zaangażowanie prowadzą do założeniowości praktycznej, co nie wyklucza wprawdzie także jej teoretycznej płaszczyzny, ale ta zwykle pozostaje kontekstowa. Praktyczna wiedza z natury jest wycinkowa, ponieważ trudno być aktorem, grać rolę będącą wycinkiem określonej rzeczywistości, a jednocześnie mieć jej całościowy, neutralny ogląd (Dehnel 2005, s. 19). Zebrany materiał badawczy przyjmuje postać idiograficzna, typową dla danego miejsca i czasu o stosunkowo niskim poziomie abstrakcji (Salzman, Rice 2009, s. 74). Stąd na podstawie zebranych informacji trudno wnioskować o prawidłowościach (typowych dla wyjaśnień nomotetycznych), natomiast pozwalają one na tworzenie wiedzy idiograficznej - swoistej, kontekstualnej (Rubacha 2010, s. 56).

Generalnie więc, zgodnie z tym założeniem, współuczestniczenie w procesach i współbycie w opisywanych i wyjaśnianych stanach pozwala lepiej zrozumieć badany obiekt i jego kontekst.

Badacz przyjmujący pozycję świadka nie zmienia badanej rzeczywistości. Uczestniczy w niej jako swoisty kibic, cechuje go jednak bezpośredni, zwykle dłuższy kontakt z badanym obiektem. Typowymi technikami stosowanymi przez niego są różne typy obserwacji. Przykładem takiej pozycji jest wykorzystanie obserwacji uczestniczącej (niejawnej) z zastosowaniem techniki cienia badanego obiektu (Czarniawska 2012, s. 73), wcielenie się w rolę kontekstowego członka zespołu, np. personelu DPS, biernego w swoich obowiązkach w relacji do badanego obiektu (Niedbalski 2010, s. 45-62), czy instytucji lub konkretnego zdarzenia. Wówczas badacz uczestniczy w świecie, ale nie odgrywa w nim istotnej roli, nie determinuje zachowań (przynajmniej w założeniach) badanego obiektu. Inaczej ujmując - nie zmienia badanej rzeczywistości. Pozycja ta przynajmniej częściowo umożliwia zachowanie dystansu i co najmniej kontekstualny (w danym miejscu i czasie) całościowy ogląd. Mimo to trudno założyć, że interpretację zebranych danych z łatwością można oddzielić od sfery emocjonalnej badacza, wszak jest on - wprawdzie biernym, ale bezpośrednim - uczestnikiem postrzeganych procesów, stanów, zdarzeń. To zaś sprzyja wrastaniu w rolę obserwowanego obiektu i przejmowaniu jego punktu widzenia otaczającej go rzeczywistości.

W nieco innej sytuacji jest aktor. Wprawdzie analogicznie jak świadek znajduje się w badanym świecie, ale w związku ze swoją pozycja odgrywa on w nim określoną rolę. Wrasta w strukturę badanej rzeczywistości i zaznacza swoją obecność, wpływając na obiekt badań. W związku z tym staje się obiektem badań lub przynajmniej uwarunkowaniem jego funkcjonowania. Granica 
między świadkiem a aktorem tylko pozornie wydaje się ostra, ponieważ świadek, np. zbierając dane za pomocą obserwacji etnograficznej, wchodzi w interakcje z badanym obiektem. Zakłada wprawdzie swoją neutralność, odgrywając rolę np. klauna lub eksperta (Eriksen 2009, s. 36), ale już sama jego obecność może modyfikować obserwowane procesy. Przykładem tego jest bierna obserwacja lekcji w szkole. Doświadczony badacz, a zarazem praktyk mający doświadczenia w pracy na stanowisku nauczyciela, zdaje sobie sprawę, że incydentalna obecność obserwatora nie pozwala na przeprowadzenie naturalnych zajęć. Wpływa ona nie tylko na zachowanie uczniów, ale także przygotowanie zajęć (zwykle bardzie przemyślane i dopracowane) przez nauczyciela. Dopiero dłuższa, systematyczna obecność badacza na lekcjach sprzyja powrotowi do powszedniości. Można zatem sformułować tezę, że świadek mimo biernej obecności czasem także staje się aktorem.

W przyjętej typologii zakładam jednak, że aktor w badanej przestrzeni odgrywa zaplanowaną rolę. Przykładem są badania w działaniu traktowane nie tylko jako metoda oceny praktycznej użyteczności teorii wypracowanych przez nauki społeczne, ale jako narzędzie wprowadzania w obiekt badań hipotetycznych czynników eksperymentalnych i weryfikowanie ich roli w określonym kontekście (Carr 2010, s. 33). W takim rozumieniu badaniem w działaniu będzie prowadzenie także typowego quasi-eksperymentu przez samego badacza (w odróżnieniu od tegoż eksperymentu prowadzonego np. przez inną osobę pod nadzorem badacza). Generalnie więc przyjmuję, że aktor w toku zbierania danych postrzega badany obiekt w sposób bezpośredni, nieustannie uczestnicząc i zmieniając badany świat, a w trakcie interpretacji danych korzysta ze wszystkich możliwych spostrzeżeń (także tych związanych z własnymi emocjami), traktując je jako swoiste dane dopełniające.

Rdzeniem badań prowadzonych przez świadka i aktora jest bezpośrednie poznanie. Może ono jednak zostać dopełnione poznaniem pośrednim, czego przykładem są badania etnograficzne, w których wiodącą rolę może odgrywać obserwacja, a rozmowy, wywiady i analiza danych stanowią techniki pomocne w gromadzeniu informacji (por. Angrosino 1998). Następstwem tego jest łączenie $\mathrm{w}$ jednym projekcie różnych perspektyw i związanych z nimi typów poznania. Zwykle jednak jedna z pozycji badacza odgrywa rolę przewodnią, a pozostałe stanowią jej dopełnienie. 


\section{Typy badaczy w badaniach nad swatem osób niepełnosprawnych - prezentacja wyników badań własnych}

Podstawowym celem prezentowanych badań było określenie częstości przyjmowanych ról i pozycji badacza w toku zbierania danych dotyczących świata osób niepełnosprawnych. Przedmiotem analizy było 110 rozdziałów prezentujących wyniki badań, a przede wszystkim zawierających opis stosowanych procedur badawczych. Zostały one opublikowane w siedmiu losowo wybranych (po jednym z lat 2007-2013) tomach pokonferencyjnych ${ }^{1}$. Zdaję sobie sprawę, że jest to dobór znacznie ograniczający wyprowadzanie szerszych uogólnień. Uzyskane wyniki traktuję zatem jedynie jako wstęp do dalszej dyskusji nad pozycją i rolą przyjmowaną przez badaczy w omawianym obszarze. Analizie zostały poddane procedury badawcze, ze szczególnym uwzględnieniem stosowanych metod, technik i narzędzi oraz opis organizacji badań, zwłaszcza gromadzenia danych. Zaprezentowane wyżej charakterystyki typów badaczy (zbieracz, myśli, świadek, aktor) posłużyły jako zbiory wskaźników umożliwiających zakwalifikowanie autora badań do konkretnego typu.

Analiza wyników badań pokazuje, że badacze świata osób niepełnosprawnych najczęściej przyjmują perspektywę zewnętrzną (zob. wykres nr 1). $\mathrm{W}$ przyjętej typologii obejmuje ona rolę zbieracza oraz myśliwego. Znacznie rzadziej - jak wykazała analiza treści tekstów - badacze lokują się wewnątrz badanego świata, przyjmując rolę świadka lub aktora.

Nie zawsze jednak - w związku z złożoną koncepcją badań - przyjmowana postawa lokuje się wyłącznie w jednym spośród wyróżnionych typów. W pięciu przypadkach stosowane procedury zbierania danych oraz opis samego badania pozwoliły zakwalifikować badaczy do dwóch, a w jednym przypadku do trzech

${ }^{1}$ I. Chrzanowska, B. Jachimczak, K. Pawelczak (red.) (2013), Miejsce Innego we wspótczesnych naukach o wychowaniu. W poszukiwaniu pozytywów, Wydawnictwo UAM, Poznań; A. Klinik (red.) (2012), Problematyka osób niepelnosprawnych w ogladzie teoretyków i praktyków, Problemy edukacji, rehabilitacji i socjalizacji osób niepetnosprawnych, t. 15, Wydawnictwo UŚ - Impuls, Katowice - Kraków; B. Antoszewska, Cz. Kosakowski (red.) (2011), Uwarunkowania i kierunki rozwoju pedagogiki specjalnej. Dyskursy Pedagogiki specjalnej, t. 10, Wydawnictwo Adam Marszałek, Toruń; B. Witkowska, K. Bidziński, P. Kurtek (red.) (2010), Dzieci i młodzież ze specjalnymi potrzebami edukacyjnymi w realizacji zadań rozwojowych, Wydawnictwo UH-P, Kielce; D. Baczała, J. J. Błeszyński, M. Zaorska (red.) (2009), Osoba z niepetnosprawnościq - opieka, terapia, wsparcie, Wydawnictwo UMK, Toruń; T. Żółkowska, M. Wlazło (red.) (2008), Socjopedagogiczne aspekty rehabilitacji osób niepelnosprawnych, t. III, Wydawnictwo US, Szczecin; B. Jachimczak, B. Olszewska, D. Podgórska-Jachnik (red.) (2007), Miejsce Innego we wspótczesnych naukach o wychowaniu, Wydawnictwo Satordruk.pl, Łódź. 
typów badaczy. Zdecydowana większość (104) jednak została zakwalifikowana do jednego typu. To oczywiście nie może dziwić, wszak analizie poddano koncepcje badawcze często skonstruowane na potrzeby konkretnego - konferencyjnego wystapienia. Te zaś sprzyjają prostemu, jednopłaszczyznowemu oglądowi niewielkiego wycinka rzeczywistości. Opis koncepcji złożonych (zakwalifikowanych do dwóch i trzech typów) zwykle opatrzony był informacją, że prezentacja wyników w artykule stanowi wycinek szerszych badań.

W stosowanych technikach badawczych zdecydowanie dominowała ankieta (wykorzystało ją 44 badaczy, co stanowiło 40\% ogółu) z zastosowaniem autorskiego kwestionariusza skonstruowanego na potrzeby badania oraz wywiad i rozmowa (użytkowana przez 28 badaczy - 26\% ogółu). W procedurach zbierania danych 23 badaczy (21\%) zadeklarowało w tekście obserwację, przy czym w 7 (6\%) przypadkach była to obserwacja uczestnicząca / etnograficzna. Ponadto 13 (14\%) badaczy wykorzystywało także skale / testy, a 20 (18\%) analizę treści. W kilku przypadkach badacze ograniczali się do podania przede wszystkim metody badań (np. eksperyment, indywidualny przypadek), nie zawsze określając stosowane techniki gromadzenia danych. Opis badania pozwalał jednak na doprecyzowanie ich pozycji wewnątrz-zewnątrz badanego świata.

\section{Konkluzje końcowe}

Analiza projektów badawczych prezentowanych w krótkich rozdziałach zawartych w pokonferencyjnych pracach zbiorowych pokazuje, że zdecydowanie najpopularniejszą użytkowaną techniką jest ankieta. Powodów tego stanu można doszukiwać się w kilku zakresach. Pierwszy wynika z przynajmniej pozornej łatwości przygotowania kwestionariusza. Jest on narzędziem niewymagającym standaryzacji, zwyczajowo nie ocenia się także rzetelności jego pomiaru, a umiejętność wskaźnikowania sformułowanych problemów badawczych należy (powinna należeć) do sprawności nabywanych już w trakcie studiów pedagogicznych. Drugi - jest efektem możliwości zbadania w krótkim czasie dużej grupy osób, trzeci - stosunkowo łatwego (przy odpowiedniej budowie kwestionariusza) przekładania danych na wartości liczbowe. Czwarty - to podejmowane problemy badawcze. Generalnie ankieta służy do badania takich zmiennych, jak: poglądy, opinie, preferencje (Rubacha 2008, s. 173). W przypadku badania świata osób niepełnosprawnych (na gruncie pedagogikipraktyk edukacyjnych czy różnych aspektów socjalizacji osób niepełnosprawnych i jej uwarunkowań) problematyka opinii i poglądów należy do istotnych. To zaś w połączeniu z tradycją badań z zakresu pedagogiki specjalnej mocno 
osadzoną w nurtach strukturalno-funkcjonalnych jest uzasadnieniem wskazanej popularności. Generalnie więc zbieracz to przede wszystkim badacz preferencji i opinii dotyczących świata osób niepełnosprawnych. W analizowanych projektach badawczych nie brakowało jednak prób nieracjonalnego wykorzystywania ankiety do pomiaru wiedzy na temat określonego wycinka rzeczywistości i przynajmniej przymiarek do wyjaśniania danych z punktu widzenia świadka. W tym kontekście uwidaczniał się problem mieszania perspektywy przyjętej na etapie gromadzenia danych z ich wyjaśnianiem / interpretacją.

Drugi z wyróżnionych typów badaczy - myśliwy - pojawiał się znacznie rzadziej, co także nie może dziwić, ponieważ analiza danych zastanych w pedagogice specjalnej należy do rzadszych technik badawczych, a jeżeli już występuje to częściej w analizach dokumentacji indywidualnego przypadku.

Chociaż w ostatnich latach, na gruncie pedagogiki, projekty badawcze osadzone w paradygmatach interpretatywnych stały się powszednie, to wśród autorów analizowanych rozdziałów (w zdecydowanej większości pedagogów specjalnych) nie cieszą się one wielką popularnością. Być może dlatego, że przyjmowana, zwykle (choć niekoniecznie zawsze) w związku z ich realizacją postawa badacza bycia wewnątrz badanego świata wymaga, prócz tych koncepcyjnych, wielu niełatwych zabiegów organizacyjnych. Pobieżna analiza ról przyjmowanych przez badaczy pozwala stwierdzić, że te utożsamiane ze świadkiem i aktorem należą do rzadkości, a szkoda, bo w przypadku wielu problemów osób niepełnosprawnych analizowanych przez badaczy nieobarczonych niepełnosprawnością wymuszają nie tylko poznanie, ale także zrozumienie problemu.

\section{Bibliografia}

Angrosino M. V. (1998), Opportunity House. Ethnographic Stories of Mental Retardation, Altamira Press, Walnut Creek, London, New Delhi.

Antoszewska B., Kosakowski Cz. (red.) (2011), Uwarunkowania i kierunki rozwoju pedagogiki specjalnej. Dyskursy Pedagogiki specjalnej, t. 10, Wydawnictwo Adam Marszałek, Torun.

Arendt H. (1991), Myślenie, Wyd. Czytelnik, Warszawa.

Baczała D., Błeszyński J. J., Zaorska M. (red.) (2009), Osoba z niepetnosprawnościa-opieka, terapia, wsparcie, Wydawnictwo UMK, Torun.

Carr W. (2010), Filozofia, metodologia i badania w działaniu, w: H. Červinková, B. D. Gołębniak (red.), Badania $w$ działaniu. Pedagogika i antropologia zaangażowana, Wydawnictwo Naukowe Dolnośląskiej Szkoły Wyższej, Wrocław. 
Chrzanowska I., Jachimczak B., Pawelczak K. (red.) (2013), Miejsce Innego we współczesnych naukach o wychowaniu. W poszukiwaniu pozytywów, Wydawnictwo UAM, Poznań.

Czarniawska B. (2012), Nowe techniki badań terenowych: shadowning, w: D. Jemielniak (red.), Badania jakościowe. Metody i narzędzia, t. 2, Wyd. PWN, Warszawa.

Dehnel P. (2005), Poznanie a społeczny świat życia, w: M. Dziemianowicz, B. D. Gołębniak, R. Kwaśnica (red.), Przetrwanie i rozwój jako niezbywalne powinności wychowania, Wyd. Naukowe Dolnośląskiej Szkoły Wyższej Edukacji TWP we Wrocławiu, Wrocław.

Eriksen T. H. (2009), Małe miejsca, wielkie sprawy. Wprowadzenie do antropologii społecznej i kulturowej, Oficyna Wydawnicza Volumen, Warszawa.

Gajdzica Z. (2009), Szkolna codzienność ucznia niepetnosprawnego - co badać, jak badać i dlaczego badać? w: D. Baczała, J. J. Błeszyński, M. Zaorska (red.), Osoba z niepełnosprawnościa - opieka, terapia, wsparcie, Wydawnictwo UMK, Toruń.

Ingarden R. (1995), Studia z teorii poznania. Wydawnictwo Naukowe PWN, Warszawa.

Jachimczak B., Olszewska B., Podgórska-Jachnik D. (red.) (2007), Miejsce Innego we współczesnych naukach o wychowaniu, Wydawnictwo Satordruk.pl, Łódź.

Klinik A. (red.) (2012), Problematyka osób niepetnosprawnych $w$ ogladzie teoretyków i praktyków, Problemy edukacji, rehabilitacji i socjalizacji osób niepetnosprawnych, t. 15, Wydawnictwo UŚ - Impuls, Katowice-Kraków.

Konecki K. (2000), Studia z metodologii badań jakościowych. Teoria ugruntowana, Wydawnictwo Naukowe PWN, Warszawa.

Kość-Ryżko K. (2013), Etnolog w labiryncie znaczeń kulturowych. Psychologiczne wyzwania badań terenowych, w: I. B. Kuźma (red.), Tematy trudne. Sytuacje badawcze, Wydawnictwo UŁ, Łódź.

Niedbalski J. (2010), Krótki epizod przynależności - „,nowy”, „normalny”, ,nieznany” wśród osób z upośledzeniem umysłowym. Problematyka tożsamości badacza w procesie eksploracji terenowej badanego środowiska, w: K. Konecki, A. Kasperczyk (red.), Procesy tożsamościowe. Symboliczno-interakcyjny wymiar konstruowania ładu i nieładu społecznego. Wydawnictwo UŁ, Łódź.

Orzechowska A, Talarowska M, Zboralski K. (2013), Wybrane trudności i dylematy etyczne w zakresie psychologicznych aspektów prowadzenia badań naukowych, w: I. B. Kuźma (red.), Tematy trudne. Sytuacje badawcze, Wydawnictwo UŁ, Łódź.

Pilch T., Bauman T. (1998), Zasady Badań pedagogicznych. Strategie ilościowe i jakościowe, Wydawnictwo Akademickie Żak, Warszawa.

Rubacha K. (2008), Metodologia badań nad edukacja, Wydawnictwa Akademickie i Profesjonalne, Warszawa. 
Rubacha K. (2010), Prawidłowości i / lub kontekst jako kryteria tworzenia wiedzy pedagogicznej, w: J. Piekarski, D. Urbaniak-Zając, K. J. Szmidt (red.), Metodologiczne problemy tworzenia wiedzy w pedagogice, Wydawnictwo Impuls, Kraków.

Salzman P. C., Rice P. C. (2009) Myśleć jak antropolog, Wyd. GWP, Gdańsk.

Schuman H. (2013), Metoda i znaczenie w badaniach sondażowych, Oficyna Naukowa, Warszawa.

Witkowska B., Bidziński K., Kurtek P. (red.) (2010), Dzieci i młodzież ze specjalnymi potrzebami edukacyjnymi w realizacji zadań rozwojowych, Wydawnictwo UH-P, Kielce.

Żółkowska T., Wlazło M. (red.) (2008), Socjopedagogiczne aspekty rehabilitacji osób niepetnosprawnych, t. III, Wydawnictwo US, Szczecin.

\section{On the position of a researcher in recognizing the world of the disabled}

\section{Summary}

What has been presented in the article is an authorial typology of researchers. It refers to the researcher's relation to the examined section of reality (inside - outside), to the type of cognition (direct - indirect) and the research subject (facts - opinions on facts). As a result of juxtaposing these three variables, researchers were, a bit metaphorically, called: collector, hunter, witness, actor. In the second part of the text, the results were presented of the analysis of research procedures comprised in 110 articles concerning the examination of the disabled's world. The notion of the world of disabled people is identified here not so much as the physically delineated environment reserved for them (e.g. institution of twenty-four-hour care or special school), but mostly as the space of limited possibilities of fulfilling life tasks. This is done with the assumption that this limitation mainly results from social attitudes and limited possibilities of the disabled person him/herself.

Keywords: typology of researchers, research of disabled. 